\title{
AZ EDUTUS EGYETEM MÜSZAKI INTÉZETÉNEK TÉRSÉGI SZEREPE KOMÁROM-ESZTERGOM MEGYÉBEN A 2021- 2024 ÉVI INTÉZMÉNYFEJLESZTÉSI TERV TÜKRÉBEN
}

\author{
DR. PEREDY ZOLTÁN, intézetvezető \\ EDUTUS Egyetem \\ peredy.zoltan@edutus.hu
}

DOI 10.47273/AP.2020.21.41-65

\begin{abstract}
ABSZTRAKT
Az Edutus Egyetem Komárom-Esztergom megye (KEM) egyetlen felsőoktatási intézményeként folyamatosan törekszik, hogy regionális innovatív tudás-és vállalkozói csomópontként (hub) működve hozzájáruljon a megye gazdasági (nemzetközi nagyvállalatok helyi gyáregységei; hazai tulajdonú kis-és középvállalatok) és társadalmi (Szakképző Centrumok, KEM Kormányhivatal, települési önkormányzatok, gazdaságfejlesztő szervezetek) szereplői közötti hálózatos együttműködések erősítéséhez, a helyi munkaerőpiac és vállalatok visszajelzései alapján oktatási, kutatás-fejlesztési és tudáshasznosítási tevékenysége színvonalának javításával, képzési, szolgáltatási portfóliójának bővítésével. Jövőbeli térségi szerepét és mozgásterét meghatározzák a megye adottságai, a 2021-2027 időszakra szóló EU célokhoz való illeszkedés.

Az esettanulmány áttekinti az Edutus Egyetem Müszaki Intézetének 2021-2027 időszakra vonatkozó lehetséges továbblépési irányait, hogy erősíteni tudja KEM-ben betöltött térségi szerepét az oktatás-kutatás-tudás üzleti hasznosítása területén. A megyei térségi szerep (regionális innovatív oktatási-vállalkozási csomópontként való működés) mellett kitekint a megyei határokon túlra országos (MIPA pilot programok digitális képzési moduljainak tananyagfejlesztése és tudásátadása különböző képzési helyszíneken és ágazatokban), illetve nemzetközi dimenziókban is (kettős diplomás képzések, EDIW workshop sorozat beindítása). Az oktatásszervezési, nemzetközi együttműködésben rejlő lehetőségek kiaknázását, társadalmi szerepvállalási javaslatok kialakítását összehangolja KEM adottságainak és helyzetének feltárásával, illetve a következő programozási időszak hazai és EU pályázati forrásaihoz való hozzáférés előfeltételéül megszabott Edutus Egyetem Intézmény Fejlesztési Terv 2021-2024 című dokumentum főbb elvárásaival.

Az elkövetkező időszak feladata a javaslatok megvalósításához szükséges források megtalálása és a szükséges humán erőforrás feltételek biztosítása. Mivel a 2021. évre áthúzódó COVID-19 járvány gazdasági kihatásai egyelőre nem prognosztizálhatók, ezért már a tervezési időszakban nagy rugalmasságra lesz szükség a célok és az erőforrás allokációk döntéselőkészítésében.
\end{abstract}


Kulcsszavak: KEM térségi szerep, intézményfejlesztési terv, regionális vállalkozói csomópont, oktatási innovációs, stratégiai céges partnerségek

\begin{abstract}
The Edutus University, as only HEI in Komárom-Esztergom county (KEM), strives continuously to strengthen the network-based, trust-building cooperation between the regional interested stakeholders (e.g.: local braches of multinational companies, domestic SME's; regional authorities, NGO's) by acting as a regional innovative knowledge and entrepreneurial hub, taking into consideration feedbacks from the local labor market actors and companies for improvement of the quality of its educational, R\&D and knowledge exploitation activities, enriching its educational, training and high added value service portfolio. Its future regional role largely depends on the regional economic and social conditions of the county and it should be alignment with the EU development and cohesion goals for the period 2021-2027 as well.

The case study reviews the future potential development directions of Edutus University Engineering Institute for the time period 2021-2027 in order to strengthen its regional role in the field of business utilization of educational and R\&D knowledge. Besides the county's regional innovative education-business hub role, extends beyond the county's borders (curriculum development and knowledge transfer of digital training modules of MIPA pilot programs in different training locations and sectors) as well as international dimensions (double diplom degree education, establishing EDIW workshop series). Defining different measures in the field of educational innovations, international cooperations, social institutional responsibility and harmonise these recommendations and ideas with the requirements of the Edutus University Institutional Development Plan 2021-2024 as well.

The task for the next period is to find the necessary human and financial resources to implement these goals. Since the economic impact of the COVID-19 epidemic beyond 2021 is not yet predictable, a high degree of flexibility will be needed in the decision-making process of resource allocations already in the planning period.
\end{abstract}

Keywords: KEM regional role, Institutional Development Plan, regional entrepreneurial hub, educational innovation, strategic corporate partnerships

\title{
1. Bevezetés
}

Az európai jármüipari központok elemzései alátámasztják azt az elméleti feltevést, hogy jelenleg a városok és térségeik együttmüködéseiben a gazdasági megfontolások kerülnek előtérbe, felülírva a közigazgatási-tervezési szempontokat az érintettek gyakran informális partnerségeket alakítanak ki a helyi gazdaság további fejlesztése érdekében. A területi egységek közötti versenyben napjainkban az érintett szereplök koordinált formában regionális hálózatokat hoznak létre, s alulról szerveződő formában alkotják meg és valósítják meg versenystratégiájukat. (Fekete 2017, 125-142 oldal)

Hazánkban több év kihagyást követően újabb elsőkörös befektetők is érkeztek (elsősorban a jármüipar belső szerkezeti átalakulási folyamatai miatt: az eddigi robbanómotorokra épülő 
összeszerelő tevékenység helyett egyre inkább előtérbe kerülnek az elektromos járművek és ezzel együtt az lítium ionos akkumulátorgyártás, valamint az ezzel kapcsolatos kérdések megoldása: az elektromos energia tárolása, kinyerése és mozgási energiává történő átalakítása). A korábbi amerikai, német, dán tulajdonú cégek mellett egyre inkább a japán, kínai és délkoreai befektetők célpontjává válik a megye.

A helyi gazdasági szereplőkkel bonyolított interjúk alapján a KEM jövőbeli kitörési pontjai az alábbiak lehetnek (amelyek részletezésre kerülnek a későbbiekben):

- Design és helyettesítő termékek

- Helyi KKV-k felkészítése, helyzetbe hozása

- Agráriumra és a hungarikumokra fókuszálás

- Turizmus fejlesztése

- A járműipar mellett a KEM gazdaság ágazati szerkezetének további szélesítése

- Külföldre távozott munkaerő „,visszavonzása, illetve a minőségi munkaerő helyben tartása megfelelő programok indításával

- Az ide betelepült cégek tevékenységei értékláncának a meghosszabbítása

Jelen cikk áttekinti az Edutus Egyetem Müszaki Intézetének 2021-2027 időszakra vonatkozó lehetséges továbblépési irányait, hogy erősíteni tudja KEM-ben betöltött térségi szerepét az oktatás-kutatás-tudás üzleti hasznosítása területén. Jövőbeli térségi szerepét és mozgásterét meghatározzák a megye adottságai, a 2021-2027 időszakra szóló EU célokhoz való illeszkedés.

\section{Nemzetközi és hazai háttér}

A gazdasági komplexitást mérő indikátor (ECI) vagy Hausmann-Hidalgo komplexitási index egy teljes körü, termelési és exportkarakterisztikákat tükröző indikátor, amely nemzetgazdaságok kereskedelmi beágyazottságán és a termékek penetrációján keresztül ítéli meg az egyes gazdaságok termelésének sokszínüségét és különlegességét. Ehhez elemezni kell az adott állam kereskedelmi kapcsolatait, valamint a gazdaság által előállított termékek elterjedtségét is. A kettőt kombinálva az ECI végül képes megmutatni egy ország exportdiverzitásából és termékminőségéből származó gazdasági erejét, ami a fogalom megalkotói szerint a fejlődési potenciál és sikeresség előre jelzője lehet. ECI elemzések megmutatják a gazdasági komplexitás és az egy före jutó jövedelem közötti eltérés alapján 
várható felzárkózási ütemet is, mivel egy ország ahhoz a jövedelmi csoporthoz konvergál hosszú távon, amely produktív tudásbázisával is szinkronban van. (Hidalgo-Hausmann 2009, 10570-10575 oldal)

A 2019. évi adatok alapján a nemzetközi ranglistán Magyarország megelőzi az Egyesült Államokat, az Egyesült Királyságot, Szingapúrt és Franciaországot, Kínát és Hollandiát a gazdasági komplexitás terén Magyarország a világ tizedik legösszetettebb gazdasága, előttünk például Dél-Korea, Németország, Ausztria, Svájc, Finnország és Svédország vannak. A V4 régióban Csehország a hatodik, Szlovákia a tizenötödik, Lengyelország a huszonegyedik helyezett a listán (Nick Routley 2019)

1. táblázat: A V4 országok iparszerkezete (2018)

\begin{tabular}{|l|c|c|c|c|}
\hline & HU & PL & CZ & SK \\
\hline $\begin{array}{l}\text { Feldolgozóipar: hozzáadott } \\
\text { érték/foglalkoztatottak aránya }\end{array}$ & $25 / 18 \%$ & $20 / 19 \%$ & $27 / 26 \%$ & $22 / 23 \%$ \\
\hline $\begin{array}{l}\text { Az export-vezérelt } \\
\text { feldolgozóipar súlya az } \\
\text { iparszerkezetben } \\
\begin{array}{l}\text { IKT szektorban } \\
\text { foglalkoztatottak aránya }\end{array}\end{array}$ & $80 \%$ & $60 \%$ & $70 \%$ & $70 \%$ \\
\hline $\begin{array}{l}\text { Feldolgozóipar és szolgáltatások } \\
\text { aránya }\end{array}$ & $55 / 45 \%$ & $48 / 52 \%$ & $59 / 41 \%$ & $61 / 39 \%$ \\
\hline
\end{tabular}

Forrás: Saját szerkesztés (Laki 2020 alapján)

A fenti táblázatból látható, hogy a Visegrádi országokban a gazdasági növekedés alapja a multinacionális feldolgozó ipari vállalatoktól jön. (OECD 2019)

\subsection{Hazai autó és járműipar}

Magyarországon az autó-és jármüiparnak hagyományai vannak. A 20. század elején már több autóépítő műhely működött az országban, míg a szocializmus évtizedeiben, a KGST-n belüli munkamegosztás keretében az autóalkatrész és az autóbuszgyártás kapott jelentős szerepet. Ezekre építve települt több autógyártó vállalat Magyarországra az 1990-es évek elejétől kezdődően és ez a folyamat napjainkban is tart. A gyártási technológiákat adaptálni képes korábbi ipari struktúrák az új piacokon megfelelő bázist jelentettek a nyugat-európai autóipari 
vállalatok barnamezős beruházásaihoz, így az autóipari körzetek fejlődésnek indultak. A rendszerváltást követő évtizedben a szocialista autóipari bázison felépített ipari központok az elsők között voltak képesek talpra állni, és az exportképes tevékenységnek köszönhetően jövedelmet és foglalkoztatást generálni a térségben. (Rechnizter et at. 2017; 124)

Az első időszakban csak gyártókapacitásokat hoztak be Magyarországra, később a termékfejlesztések egy része is átkerült ide. A korábbi haszongépjármü-gyártást átvette a személygépkocsik előállítása, így indult el Magyarországon az Audi, Mercedes, Opel és Suzuki típusú személyautók gyártása. Jelenleg 5 autógyártó cég (OEM) létesített gyártó üzemet Magyarországon (Audi, BMW, Mercedes, Opel, Suzuki), további három OEM (Ford, Nissan, JLR) pedig mérnöki és szervízszolgáltatásokat hozott hazánkba. Magyarországon jelenleg 740 autóiparhoz kötődő vállalat müködik és ezek 180 ezer embert foglalkoztatnak. Az iparág számos üzleti területet foglal magába, az alkatrészek és kiegészítők gyártásától kezdve, a logisztikai szolgáltatásokon át, a gépjárművek teljes gyártásáig. Az e-mobilitás, a digitalizáció, az autonóm, önvezető járművek, a CO2-kibocsátás, a szakképzett munkaerő hiánya új és sokoldalú kihívásokat jelentenek az iparág számára (HIPA 2019)

A fenti trendeknek térszerveződési és technológiai folyamatszervezési okai is vannak: Az autóipari szektor globális méretüvé válásával a vállalati szervezeti rendszer és munkamegosztási folyamatok rendszere előtérbe került. Átalakult az OEM anyavállalat és telephelyei, valamint a beszállítói közötti kapcsolat. átalakítva ezzel az autóipar térbeli szerveződését. A vállalati tevékenység földrajzi mintázatának átalakulását számos tényező befolyásolta, többek között a kereskedelempolitikai döntések vagy a szállítási és a távközlési rendszerek fejlődése. Az iparágban elengedhetetlen az autóipari alvállalkozók, a logisztikai partnerek és a gyártók közötti zökkenőmentes koordináció, az autóipar az egyik legnagyobb kihívást jelentő iparág az automatizált beszerzési folyamatok tekintetében. A minőségi, időben történő szállítás és az átlátható logisztikai folyamatok mellett, a nagyfokú rugalmasság és a rövid válaszidő is szükséges, hogy a részegységek a megfelelő időben kerüljenek a gyártósorra. A széles körüen alkalmazott lean elvek alapja, hogy a termelés során folyamatosan csökkentik a költségeket, így szüntetik meg a nem értéktermelő műveleteket (Tóth 2007).

A hatékony és rugalmas termelési folyamatnak köszönhetően időt és költséget takarítanak meg. Az OEM cégek az értéklánc egyre több tevékenységét szerveztek ki a beszállítóiknak, lényegében csak a tervezést és a végösszeszerelést tartva meg házon belül. Emellett a moduláris rendszerü termelés, a technológiai és munkaszervezési újításokkal együtt lehetővé tették az iparág globalizációját. A moduláris rendszer a gyártástervezés során szabványosított 
kapcsolódási felülettel (csatlakozások és kompatibilitás) rendelkező, önálló funkcionális egységek sorozatával az adott célnak megfelelő, sokoldalú alkalmazásra használható egységeket alakítanak ki (az egyes típusok, modellosztályok közötti csereszabatos alkatrészek). Az egyes modulok és azok részegységeinek előállítását, összeszerelését a beszállító vállalatok végzik. A modularizáció és a kiszervezés miatt az első körös (TIER1) beszállítók feladatai megnőttek. A többletfeladatokhoz tőkeigényes vállalatokra volt szükség, ami az iparág konszolidációjához vezetett. A TIER1 vállalatok egyszerre több, egymás versenytársainak számító autógyárral is kapcsolatban és globálisan szervezik partnereik áruval és szolgáltatással történő ellátását. (Túry 2017, 51-54 oldal)

Magyarországon az ipari termelés meghatározó részét, 96\%-át a feldolgozóipar adta. Termelési értéke 2019-ben közel 33 ezer milliárd forint volt, összehasonlító áron 5,5\%-kal magasabb a 2018. évinél. A jármügyártás 2019-ben a feldolgozóipari termelés 29\%-át állította elő, 4,8\%kal meghaladva az egy évvel korábbi volument. A közútigépjármü-gyártás volumene 2,3 \%-kal míg a közútijármü-alkatrész gyártásáé 5,3\%-kal emelkedett. Ez azonban még tovább növekedhet, ha megindul a gyártás a BMW debreceni gyárában. A jármügyártás a 2008-2009es recessziót megelőző és azt követő években a gazdasági növekedés alapja volt, 2016-2018 között azonban számottevően veszített korábbi lendületéből, és ebben az időszakban már lassította, visszafogta az ipar bővülését. 2019-ben viszont az iparág kibocsátása 9,8\%-kal már meghaladta az egy évvel korábbit. A növekedés sajátossága, hogy eközben az EU-ban csökkent (4,3\%-kal) a jármügyártás volumene. Emellett széles körü beszállítói rendszerei révén hatással van más alágakra (többek között az elektronikai iparra, a gumi- és műanyagiparra, valamint a kohászat, fémfeldolgozásra) is, így teljesítménye számottevően befolyásolja az egész ipari termelés alakulását. A külkereskedelem szempontjából is kiemelt szerepe van a jármüiparnak, hiszen az export ötöde származik ilyen tevékenységből.2017-re már a 8000 milliárdot is meghaladta. A teljes magyar ipari termelés 18, a GDP-nek pedig 10\%-át adja a jármüipar. A jármügyártó cégek árbevételének 92\%-a külpiacokról jön, a Magyarországon gyártott motorok négyötödét, az autók 97\%-kát exportálják. (KSH 2020; 90)

\subsection{Komárom-Esztergom megye helyzete}

Az 1990-2020 közötti időszakban Komárom-Esztergom megye (KEM) regionális adottságai az országos összehasonlításban átlagon felül kedvezőbb helyszínt jelentettek és jelentenek ma is a nemzetközi nagyvállalatok magyarországi telephelyeinek helyszínválasztásához elsősorban a jármüipar területén 
- KEM az egy fóre jutó bruttó hazai termék (forint) tekintetében a negyedik Magyarországon. A sorrend: 1.) Budapest (6.842 ezer Ft/fö), 2.) Győr-Moson-Sopron (4.068 ezer Ft/fö), 3.) Vas (3.292 ezer Ft/fö) és 4.) Komárom-Esztergom (3.253 ezer $\mathrm{Ft} / \mathrm{fö}^{\prime \prime}$. A megye eredménye megközelíti az országos átlagot (3.262 ezer Ft/fó), annak a $99,7 \%$-a.

- KEM az ország területének 2,4\%-át fedi le, lakónépességének 3\%-át adja, a foglalkoztatottak 3,2 százalékát biztosítja, a hazai regisztrált vállalkozások 2,4\%-a található meg a területén. A beruházások teljesítményértékének országon belüli aránya (5\%) lényegesen magasabb, mint lakosságaránya, ugyanez hatványozottan igaz az ipari termelésre12 $(8,3 \%)$.

- A megyei székhelyü ipari vállalkozások termelése összesen 11\%- kal, ezen belül a járműipari cégeké 17\%-kal bővült. Az építőipari termelés 6,3\%-kal nőtt, a vállalkozások a tavalyinál 20\%-kal magasabb értékű kivitelezési munkára kötöttek új szerződést.

- A KSH munkaerő-felmérése alapján 2016 második negyedévében KomáromEsztergom megyében az aktivitási arány $61,3 \%$ volt. A gazdaságilag aktív népesség 141,3 ezer főt tett ki, számuk mintegy 900-zal kevesebb, mint előző év azonos időszakában. Ezen belül a foglalkoztatottaké 1,7 ezer fővel nőtt, a munkanélkülieké 2,6 ezerrel csökkent.

- A munkanélküliségi ráta 2,8\%, a foglalkoztatási ráta 59,6 \% volt 2016. első félévében, az országos adatok: $5,1 \%$ és $57,8 \%$. Elmondható, hogy mind a két mutató tekintetében a megye kedvezőbb helyzetben van, mint a magyar átlag

Látható, hogy bár KEM kis területü megye, de a tatai medencében jelentős gazdasági potenciál halmozódott fel 1990-2019 között. (Tatabánya Foglalkoztatási Stratégiája 20110$2021 ; 10-12$ oldal)

Az első ábrán a KEM különböző ipari parkjainak területi megoszlása látható. Ennek alapján megállapítható, hogy mind terület, mind az ide betelepült cégek számát tekintve a Tatabánya/Környe, illetve a Komáromi Ipari Park a legjelentősebb. Az 1997-ben az országban az elsők között létrejött Tatabányai Ipari Park a jelenlegi 800 ha-t meghaladó alapterületével Magyarország egyik legnagyobb ipari parkjaként van számon tartva.(Az elmúlt 15 év alatt 10 ezer munkahely létesült itt 1 milliárd EURÓ összegű működőtőke befektetéssel). Az ipari park 
cégei eltérő iparágakban tevékenykednek, a legjelentősebb szektor az autóipari beszállítók, de megtalálhatóak gépipari, építőipari, logisztikai, elektronikai, gyógyászati segédeszközöket gyártó vállalatok is. Oroszlányi Tudományos és Technológiai Park 2016 decemberében, az országban kilencedikként, Komárom-Esztergom megyében pedig elsőként szerezte meg a „Tudományos és Technológiai Park” címet.

1. ábra: Komárom-Esztergom megye ipari parkok területi megoszlása (2019)

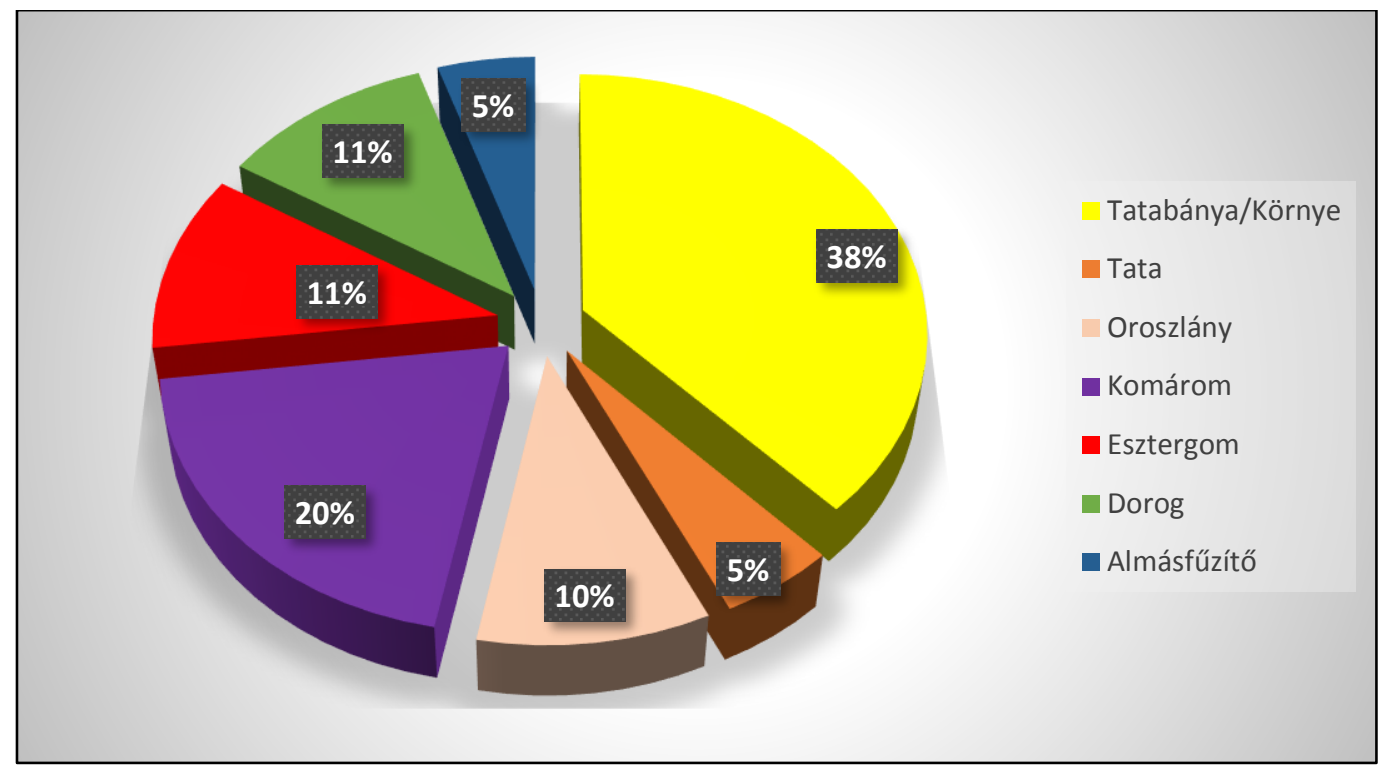

Forrás: Saját szerkesztés (GFSZ Tatabánya belső információs rendszer alapján)

A második ábrán néhány KEM ipari park cégei által foglalkoztatott munkavállalói létszám látható

2. ábra: A néhány KEM Ipari Park cégeinek foglalkoztatotti létszámadatai (2019)

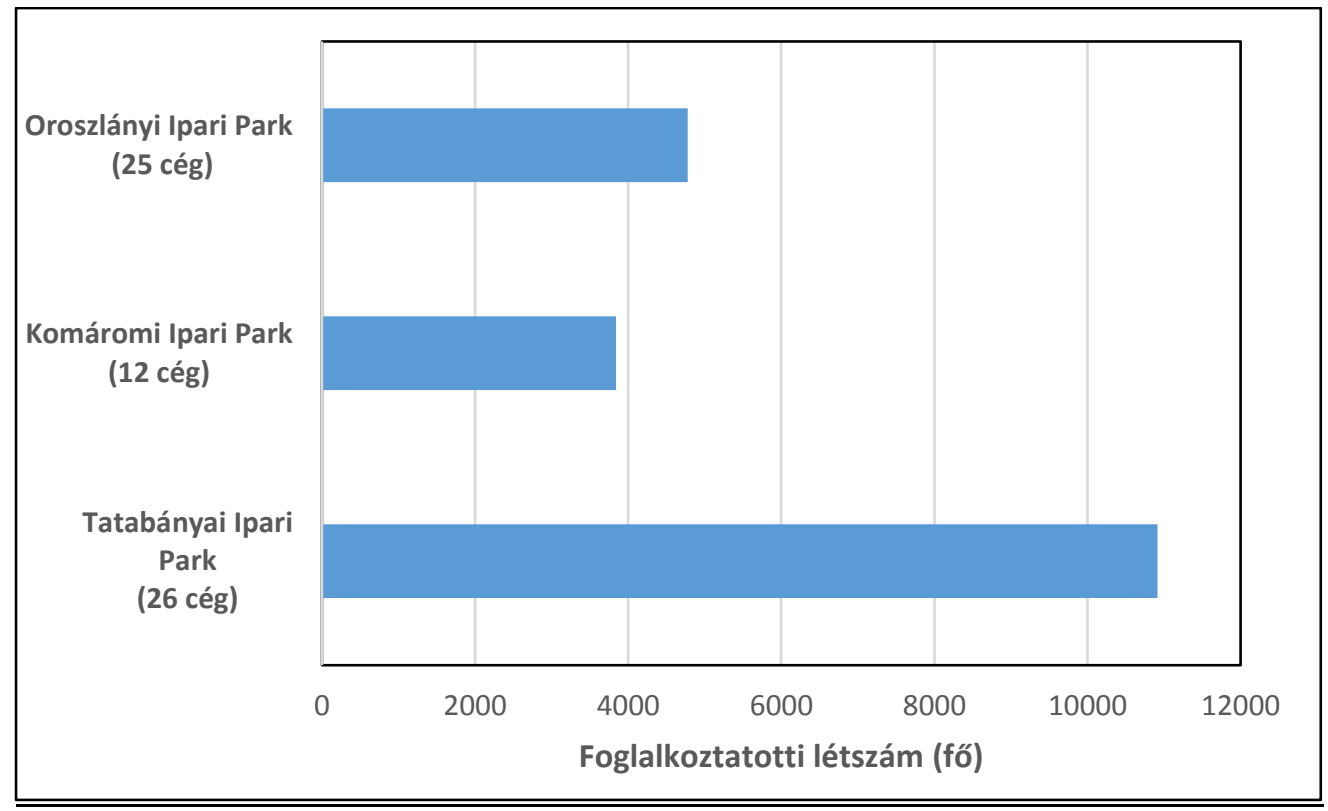


Forrás: Saját szerkesztés (GFSZ Tatabánya belső információs rendszer alapján)

A 3. ábrán a Tatabánya Megyei Jogú Város iparüzési adó bevételeinek alakulása látható, amelyek zömmel a Tatabánya/Környe ipari parkba betelepült (elsősorban, de nem kizárólagosan autóipari profilú) nemzetközi nagyvállalatok helyi gyártó/összeszerelő egységei révén realizálódtak.

3. ábra: Tatabánya megyei jogú város iparüzési adó bevételei (2011-2018)

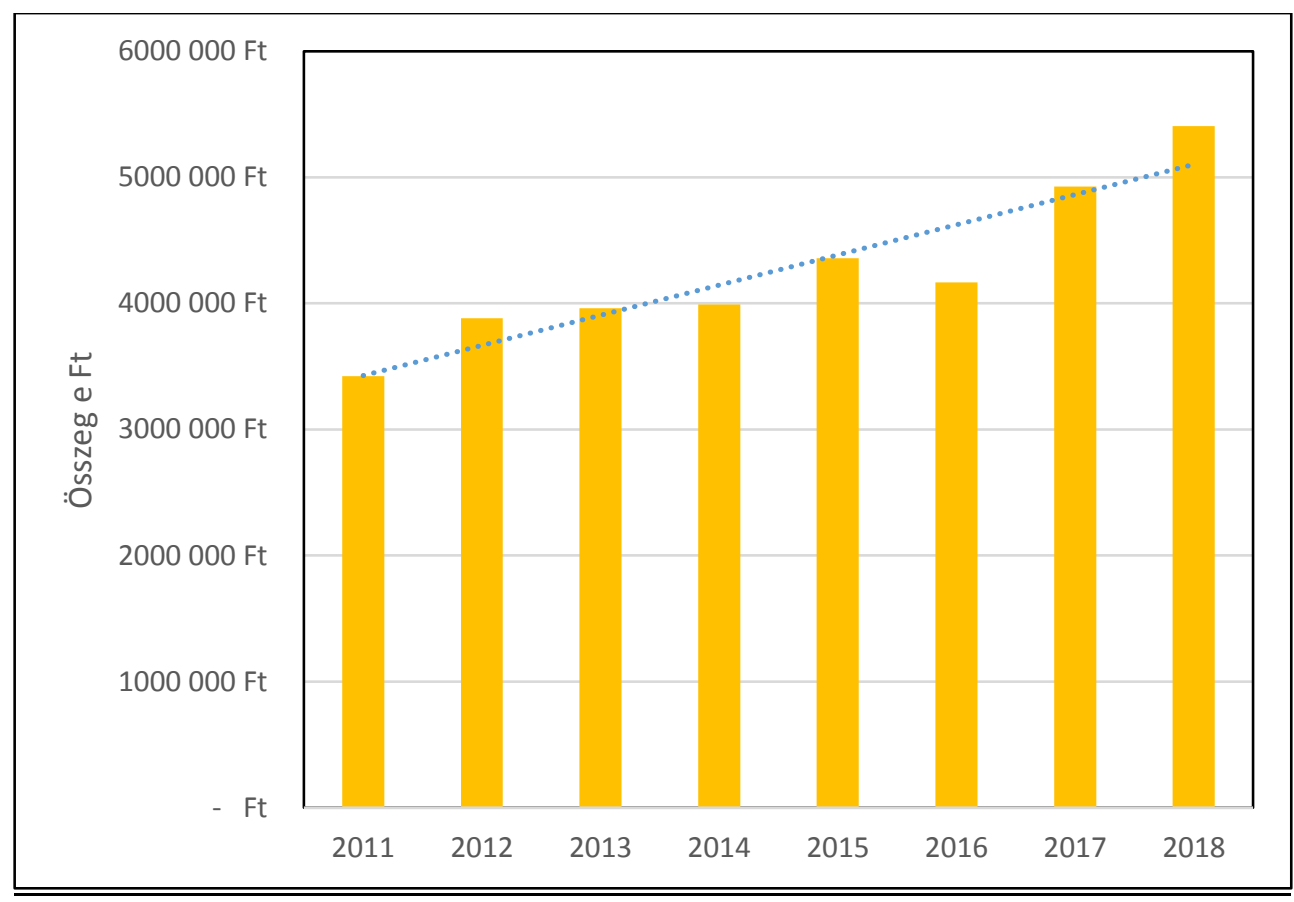

Forrás: Saját szerkesztés (Munkaügyi Központ Tatabányai Kirendeltség adatai alapján)

\subsection{Komárom-Esztergom megye gazdaságának további fejlődési lehetőségei}

A nagy európai járműipari központok vizsgálatánál az érintett szereplők közötti együttmüködés vizsgálatának főbb fókuszpontja: 1) Milyen szerepet tölt be jármüipar a térség gazdaságában? Járműipari cégek révén realizált adóbevételek, közös oktatási és kutatási infrastruktúra beruházások mértéke, járműipari cégek társadalmi felelősségvállalási politikájának helyi kedvezményezettjei; 2) Milyen a jármüipari térség együttműködési és pályaorientációs modellje? Hogyan teremtik elő az ehhez szükséges forrásokat? Az egyeztetések milyen rendszerességgel és napirendi pontokkal történnek? Milyen szerepet játszanak a térségben lévő felsőoktatási és szakképző intézmények?; 3) Milyen szerepet vállal az önkormányzat a gazdasági szereplőkhöz kapcsolódó infrastruktúra fejlesztésben (ipari park, úthálózat-és közmüfejlesztés, szellemi és intézményi háttér biztosítása, logisztikai központ)? Hogyan 
alakítja a helyi adózási viszonyokat? Milyen segítséget nyújt a pályaorientációban, az MTMT pályák iránti érdeklödés felkeltésében? A térségi települések között van-e intézményesített együttmüködés? (Fekete 2017, 129-130 oldal).

A KEM ipari parkjaiban betelepült nemzetközi nagyvállalatok elsőkörös beruházásait az évek során második, harmadik és negyedik körös (kapacitásbővítő vagy diverzifikációs célú) újabb befektetések követték egyre magasabb hozzáadott értékü termelési tevékenységet hozva a megyébe.

A nemzetközi nagyvállalatok beszerzései globálisan központosítottak (követelmények, ártárgyalások), a megyébe való betelepülés esetén a gyáregység hozza magával külföldröl a bevált beszállítóit. A jármüipari beszállítói lánc termék alkatrész (direkt) beszállítói részébe (TIER1 és TIER2) nem igazán tud ezek miatt bekerülni magyar KKV. Ennek okai: 1) A KKVknak komoly gyártásfejlesztéseket (tőkeigényes technológiai és termelésszervezési fejlesztéseket) kell végrehajtaniuk, hogy a megrendelő számára tényleges hozzáadott értékkel bíró termékeket gyártsanak; 2) A járműipai beszállítók esetében speciális termék és folyamat minőségbiztosítási protokolloknak is meg kell felelniük (IAFT 16949), aminek célja, hogy bizalmat alakítsanak ki a részszállítók és szolgáltatók egymással és az autógyárakkal; 3) Az egységes követelményeknek való megfelelés során az OEM vagy a beszállítói láncban a cég felett álló megrendelő elvárja, hogy a beszállító KKV évről évre folyamatosan csökkentse az árait a költséghatékonyság jegyében a növekvő munkaerő költségek, a technológiaifejlesztések forrásigénye és az alkatrészek szerkezeti anyagainak tőzsdei árfolyamváltozásaitól függetlenül (például az alumínium öntvények tőzsdei ára folyamatosan ingadozik); 4) A helyi beszállítók tendereztetése esetén magának a nemzetközi vállalat KEM gyáregységének is erőforrásokat kell átcsoportosítani erre a feladatra (termelési kapacitása egy részét ki kell vonni a napi termelési feladatokból, hogy a potenciális beszállítók termékeit tesztelje valós körülmények között). Ez számukra is kockázatokat, bizonytalanságokat hordozó folyamat, nem szívesen foglalkoznak ezzel.

A KEM gazdasági szereplöivel történt interjúk alapján a KEM jövőbeli kitörési pontjai az alábbiak lehetnek:

a) Design és helyettesítő termékek

Annak feltérképezése, hogy milyen termékek válthatók ki rentábilisan külföldi beszállítóktól jó minőségü helyi termékekkel. Ezek a V4 országok (60-80 milliós belső piac) vagy a Nyugatbalkáni országok (20 milliós belső piac) esetében nagy üzleti lehetőséget jelentene, de ezzel 
jelenleg senki sem foglalkozik. (Pedig a KEM ipari parkjaiba betelepült cégek által létrehozott munkahelyek fizetőképes keresleteit is célszerü lenne helyben előállított termékekkel és szolgáltatásokkal kielégíteni).

b) Helyi KKV-k felkészítése, helyzetbe hozása

Saját termékekkel, saját piacokra lépésre vagy beszállítói láncban magasabb szinten való bekapcsolódásra (elsősorban a gyártási folyamatokhoz szükséges berendezések, gépek karbantartási és alkatrész utánpótlási feladataira, létesítmény-üzemeltetési, energetikai és hulladékgazdálkodási feladatok, nagy tömegü adatok valós idejü feldolgozásával kapcsolatos technológiai/szolgáltatási megoldások nyújtására - indirekt beszállítói feladatokra) lenne szükség

c) Agráriumra és a hungarikumokra fókuszálás

Ez utóbbi egységes osztályozási, besorolási és nyilvántartási rendszerben olyan megkülönböztetésre, kiemelésre méltó értéket jelöl, amely a magyarságra jellemző tulajdonságával, egyediségével, különlegességével és minőségével a magyarság „csúcsteljesítménye."

d) Turizmus fejlesztése

KEM előnye: a szomszédos megyékkel és a határon túli területekkel is vannak területfejlesztési társulásai, amelyek plusz forrás és infrastruktúra bevonást tesznek lehetővé.

e) A járműipar mellett a KEM gazdaság ágazati szerkezetének további szélesítése Vegyipar, gépipar, egészségipar területén lehetne kiaknázni a megye kapcsolatrendszerét és lobbi erejét.

f) Külföldre távozott munkaerő „,visszavonzása, illetve a minőségi munkaerő helyben tartása megfelelő programok indításával

g) Az ide betelepült cégek tevékenységei értékláncának a meghosszabbítása

Bizalomépítéssel, stratégiai gondolkodásmóddal: korrektség, kiszámíthatóság, átláthatóság, professzionalizmus - ezekkel lehet elérni, hogy a gyártás-összeszerelés mellett fejlesztési és vagy marketing/disztribúciós tevékenységeket is ide telepítsenek az eddigi befektetők. 


\section{Az Edutus Egyetem Intézmény Fejlesztési Terve (2021-2024) és a Müszaki Intézet}

3.1. A 2021. március 31-ig kidolgozásra kerülő Edutus IFT 2021-2024 főbb szakmai fókuszpontjai

1) Oktatás

A felsőoktatási képzési kimenetek átjárhatóságának és alternatíváinak növelése; a felnőttképzési és szakirányú továbbképzési tevékenység megerősítése; a felsőfokú képzés tartalmi megújítása, összhangban a munkaerő-piaci, helyi társadalmi-gazdasági igényekkel; a hallgatói és oktatói-kutatói nemzetközi mobilitás növelése; az oktatási innováció terén a felsőoktatásban használt oktatásmódszertan gyakorlat- és hallgatói munkavégzés központúvá tétele; az oktatói kiválóság növelése érdekében az oktatók teljesítményközpontú elömeneteli rendszerének és versenyképes bérezésének megteremtése.

2) Kutatás-fejlesztés és innováció

A technológia-intenzív KKV-k - innovációs kompetenciájának fejlesztése; a nemzetközileg versenyképes minőséget és az erőforrás-koncentrációt támogató kutatásfinanszírozás, valamint az állam-háztartáson kívüli, az intézmények által megszerzett forrásokra való építés erősítése; az intézmények ipari kapcsolatainak erősítése, innovációs és ipari központok kiépítése; intézmények közötti $\mathrm{K}+\mathrm{F}+\mathrm{I}$ hálózatok kialakítása az intézményi $\mathrm{K}+\mathrm{F}+\mathrm{I}$ fókusz erösítésével; a $\mathrm{K}+\mathrm{F}+\mathrm{I}$ célú infrastruktúra megújítása, ezek humán erőforrás oldalának biztosítása.

3) Harmadik misszió

A helyi gazdaságfejlesztésre gyakorolt intézményi hatás erősítése; a tudománynépszerüsítő, ismeret-terjesztő, szemléletformáló szolgáltatások bővítése, és a felsőoktatási tudásbázishoz történi ingyenes hozzáférés növelése; az intézmény aktivitásának növelése a társadalmi kihívások kezelésében és a társadalmi innováció terjesztésében; a felsőoktatás szolgáltató funkcióinak megerősítése mind a hallgatók, mind a helyi társadalom felé.

4) EU célokhoz való hozzájárulás

Speciális képzések az intelligens szakosodás területén történő átképzést és továbbképzést, az innováció-menedzsmentet, a vállalkozói készségeket és a vállalatokon belüli innovatív üzleti modelleket illetően, figyelmet fordítva az ipari átalakulással és a körforgásos jelleggel kapcsolatos szükségletekre; a készségfejlesztés üzleti igényekhez történő igazításra; digitális készségek elsajátításának, a digitális oktatás-tanulásnak a támogatása minden intézményi dolgozó és hallgató számára; oktatási és képzési infrastruktúra fejlesztésének támogatása; 
kulcskompetenciák fejlesztése minden intézményi hallgató és dolgozó számára, a munka világába való zökkenőmentes átmenet elősegítése.

5) Kiemelt képzési területek

Müszaki képzések (az alapképzések és mesterképzések szerkezeti felépítésének megújítása; a felsőoktatási intézmények és a végzetteket alkalmazó cégek közötti partnerség kialakítása és ennek szabályozása; megfelelő felkészültségü hallgatói bemeneti kör biztosítása az MTMI képzések számára a hallgatói sikeresség javítása érdekében.

Gazdaságtudományi képzések (A gazdasági mesterszakok kínálatának szélesítése, a helyi munkaadókkal együttműködve; a nemzetköziesítésben rejlő lehetőségek kihasználása, a versenyképes, idegen nyelvű képzések erősítése elsősorban a mesterszakokon)

\subsection{A Müszaki Intézet néhány, 2020. évi oktatási-kutatási infrastruktúra fejlesztési eredménye a vállalati kapcsolatai révén}

Az Edutus Egyetem Müszaki Intézetének küldetése, hogy megteremtse a korábban hiányzó müszaki felsőoktatás feltételeit, és koordinálja a Komárom-Esztergom megyében folyó müszaki képzéseket, amelyek jelenleg az alábbi szakokon folynak:

- Mechatronikai mérnök: Lézertechnológia illetve karbantartó (2020-2021-1 félévtől) specializációs irányokkal. (alapszak)

- Műszaki menedzser: Folyamat és projektmenedzsment valamint minőségmenedzsment (2020-2021-1 félévtől) specializációs irányokkal (alapszak); létesítménygazdálkodás (alap és mesterszak)

A Müszaki Intézet széleskörü, több szintü kapcsolatrendszert épített ki és tart fenn a KEM ipari parkjaiba betelepült nemzetközi nagyvállalatok magyarországi gyáraival, illetve a hazai alapítású és tulajdonú cégekkel. A cégek üzleti tevékenységeik során közvetlenül vagy közvetve kapcsolódnak a jármüipar különböző szegmenseihez, emellett kielégítve egyéb szektorok megrendeléseit is. Az intézményközi együttmüködések felölelik a duális képzéseket, a hallgatók részére szakmai gyakorlati helyek biztosítását, a cégek igényeinek megfelelő, kihelyezett tréningek megtartását, a gyakorlat-orientált müszaki alapszakos és mesterszakos képzésekbe a vállalati/gazdasági igényeknek a becsatornázását, a vállalati szponzoráció keretében történő egyetemi kutatási infrastruktúra-fejlesztéseket, magas hozzáadott értékű, egyedi ipari megbízások megrendelését. A stratégiai céges partnerség néhány látványos 2019- 
2020 évi eredménye (illeszkedve az oktatási és kutatási infrastruktúra megújításához, valamint a felnőttképzési tevékenység megerösítéséhez).

a) Bridgestone Tatabánya Kft. Szállítószalag pálya CE megfelelősséggel

A gyakorlati oktatást segítő szállító pálya szakasz 3 darab, különböző típusú szállítószalagból áll (egyéni görgőhajtás (szíjhajtás, görgőhajtás), Karakuri megoldással (intelligens automatizáció - lejtős kialakítással rásegítés az anyag továbbítására) kombinálva. A középső rész a szállítószalag pálya elindulásakor felemelkedik, szintbe kerül az első egységgel, majd a munkadarab rákerülése után lebillen és átmenetet biztosít a harmadik egységhez, amelynek a végén megáll a munkadarab. Az egység alkalmas a különböző karbantartási feladatok bemutatása mellett logisztikai és automatizálási problémák oktatására is. Főbb méretek $\mathrm{H}=295$ $\mathrm{cm} ; \mathrm{Sz}=110 \mathrm{~cm} ; \mathrm{M}=95 \mathrm{~cm}$. A szállítószalag pálya érvényes érintésvédelmi és $\mathrm{CE}$ megfelelőségi tanúsítvánnyal rendelkezik (ez utóbbi az mutatja, hogy a berendezés megfelel a gépek biztonságáról szóló 2006/46/EK irányelv előírásainak)

4. ábra: Bridgestone szállítószalag pálya (jobbra) és a CE megfelelőség (balra)
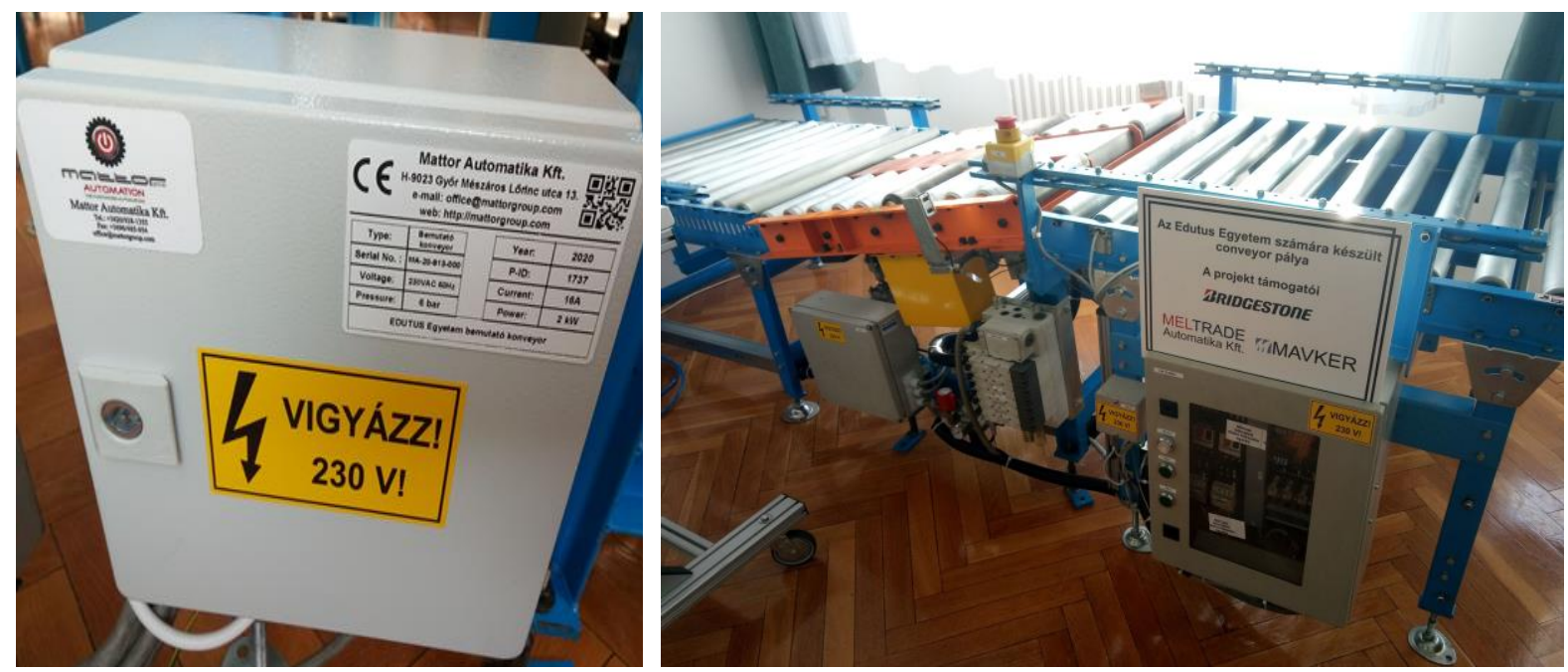

Forrás: Saját fénykép

b) Közreműködés a Cella Vezető Bridgestone Akadémia képzésben

A Bridgestone Tatabánya Kft. célja, hogy a legjobb technikusait közép vezetővé (müszakvezető) léptesse elő, de ezt egy iskolarendszeren kívüli, egyéb felnőttképzési kategóriába tartozó, három féléves modulból álló, modulonként 6-7 tárgyat (30-35 kredit) tartalmazó, az Edutus Egyetem által tartandó képzés elvégzéséhez köti. A Cella Vezető Bridgestone Akadémia nevet kapott céges képzésben 10 fő munkavállaló vesz részt, a Müszaki Intézet a 2020-2021-1 félévben két tárgy (Mérnöki alapismeretek, valamint a Gumiipari Kémia és Anyagismeret) oktatásában volt érintett. 
c) B\&O Engineering Kft. RINCO MP351 UH hegesztő berendezés átadása a MIT részére

5. ábra: Az amorf és részben kristályos müanyagok hegesztésére alkalmas $35 \mathrm{KHz}$ frekvenciájú analóg ultrahangos berendezés

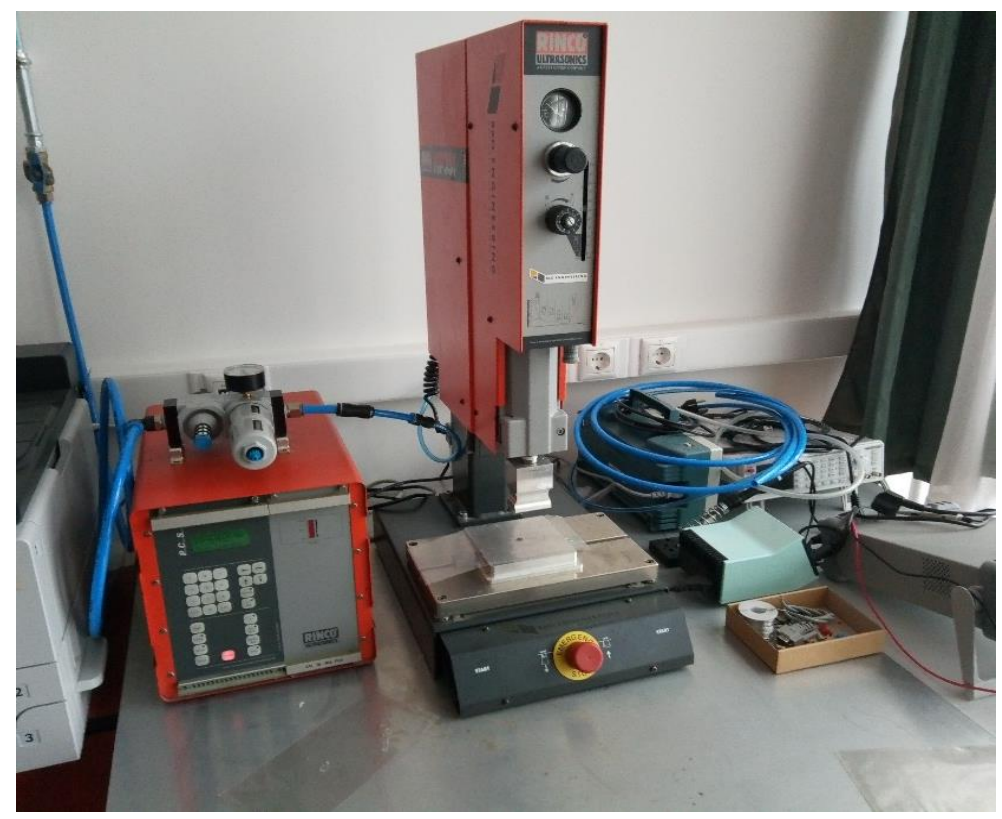

Forrás: Saját fénykép

d) Coloplast Hungary Kft - YAMAHA YK600-X típusú, SCARA robot

A Coloplast Hungary Kft. által adományozott SCARA robottal lehetővé vált a robottechnikai oktatás „színesítése” egy kisméretű, manipulátor típusú feladatokra alkalmas típussal. A motor tengelye egy tengelykapcsolón keresztül kapcsolódik a hajtott tengelyhez, így növelve a merevséget, mozgási sebességet és pontosságot, valamint csökkentve a szervizigényt. Széles körben alkalmazható, mint például elektronikai gyártás, kisméretű precíziós alkatrészek gyors mozgatása, palettázása, szerelése, nagyobb méretű alkatrészek mozgatása. (Max. terhelhetőség: 5 kg; Mozgási tartomány: 120-1200 mm; Ismétlési pontosság: +/- 0,01 mm (X, Y, Z tengelyek); Max. sebesség: 4,9 m/s (X, Y tengelyek); 1,1, m/s (Z tengely) 
6. ábra: YAMAHA SCARA robot szabvány robotcellával és vezérlőegységgel

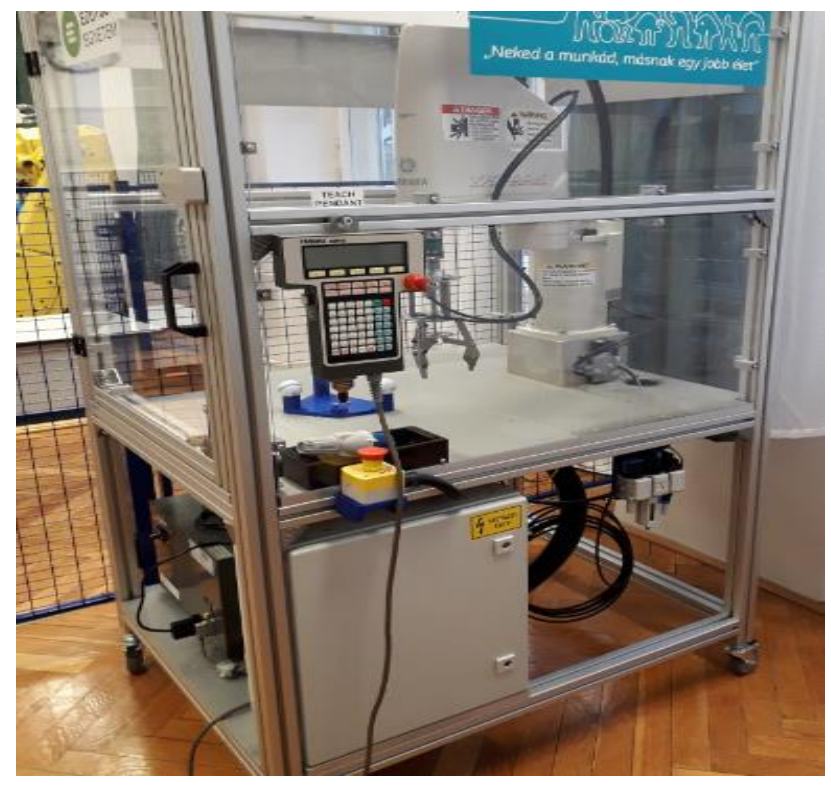

Forrás: Saját fénykép

\section{Következtetések, javaslatok}

Az Edutus Egyetem Müszaki Intézet részéröl célszerü elmélyíteni a KEM gazdasági szereplőivel (például TSZC jogutóda, GFSZ Tatabánya, Ipari Parkok, KEM VOSZ, KEM KIK, KEM Agrárkamara, illetve a KEM cégekkel) a korábban megkezdett közös együtt gondolkodást. Az ennek alapján megvalósítandó elképzelések mindegyik fél számára valamilyen előnyöket kell, hogy biztosítson (például közös kutatás-fejlesztési, vagy oktatási projektek, közös osztott infrastruktúra használat, a KEM gazdasági szereplői közötti bizalomépítés, szemléletformálás, adott aktuális témákra való érzékenyítés). Ezeknek a lépéseknek az IFT 2021-2024 dokumentumban foglaltakkal összhangban kell majd történnie az alábbiak szerint:

Harmadik misszió

- Gazdasági Klub és Vállalkozói Fórumok megszervezésében és lebonyolításában való közremüködés. Ennek egyik legjobb eszköze, ha a klasszikus vállalkozói fórumok helyett ágazatonként modern workshopokat szervez az Edutus Egyetem: 5-6 fös csoportokban leül az érintett cégek képviselőivel és facilitátor segítségével megoldási javaslatokat dolgoz ki a felmerülő konkrét problémákra, és ezek eredményeit pedig publikálja.

- Hálózatos együttműködések elősegítése, bizalomépítés. Erre egy példa lehet a Vida Jenő Asztaltársaság. A Tatabánya MJV által kezdeményezett asztaltársaság létrehozásával egy olyan találkozási pontot hoztak létre, amely elősegíti a város és a 
megye fejlődését, ahol a megye gazdaságát tovább tudják fejleszteni az érintett szereplök bevonásával egy szakmai programokkal „tarkított” kötetlen eszmecsere keretében.

- Edutus Passzív Ház - szakmai és népszerüsítő, szemléletformáló rendezvények, bemutatók szervezése közoktatási intézményeknek, civil szakmai szervezeteknek megújuló energetika, fenntarthatóság, zöld gazdaság témákban. (Erre példa: a Nemzeti Müvelődési Intézet és a Magyary Zoltán Népföiskolai Társaság szervezésében Népfőiskolai Mühelysorozat zajlik Tatán 2019 ösze óta a „Müvelödő közösségek ÉszakMagyarországon” címü, EFOP-3.7.3-16-2017-00148 azonosítószámú projekt kereteiben. A 12 alkalommal, havonta megvalósuló mühelyfoglalkozás célja a közösségi szerepvállalás fontosságának megismertetése a környezetvédelem tükrében. A résztvevők két alkalommal látóútra indulnak, hogy az elmélet mellett a gyakorlatban megvalósult, klímavédelemmel összefüggő beruházásokat is megtekinthessenek, megismerve a helyszínen azok működési rendszerét, mérhető eredményeit. Így került sor az Edutus Egyetem passzívházának meglátogatására is 2020 őszén).

Európai célokhoz való hozzájárulás

- Képzések, szemléletformálás, érzékenyítés (generációváltás, innovációmenedzsment, klímaváltozás, digitalizáció, vállalkozásösztönzés, üzleti tanácsadás)

- Az ipari átalakulási trendek miatt szükséges kulcskompetenciák fejlesztése érdekében

- a robotikai oktatás színvonalának emelése (Fanuc Hungary Kft-val való stratégiai megállapodás kereteiben)

- Edutus WRO (amely a robot építés és programozás alapjaira készíti fel a fiatalabb korosztályokat Lego Mindstorme EV-3 és Tetris modulokkal érzékenyítés), valamint a Fanuc Hungary $\mathrm{Kft}$. általl szponzorált Euroskill/Worldskill Robotics rendezvények (amely Fanuc robotra adaptált integrált robotcella építő feladatok - szakmai profizmus) összehangolása

Oktatás, kiemelt müszaki képzési területek

A jövő problémáit nem a jelen szakemberei fogják megoldani, hanem ezekhez új készségekkel rendelkező jövőbeli szakemberek kellenek. Ilyen képzésekben, „szintre hozásban” katalizátor szerepe lehetne az Edutus Egyetemnek, azaz a KEM számára szükséges magasan képzett helyi munkaerö biztosításában és itt tartásában (amire célszerü lenne külön forrást is találnia). Néhány ígéretes jövőbeli, nagy üzleti potenciállal bíró oktatási terület:

$\mathrm{Az}$ iskolarendszerü képzések esetében: 
- A 7 féléves alapszakos müszaki képzések kínálatának bővítése a cégek igényei/visszajelzései alapján (MeMé BSc. karbantartó - amelyhez szükséges oktatási eszközöket a Bridgestone Tatabánya Kft. biztosítja, MüMe minőségmenedzsment specializáció), illetve valamennyi szakon mérnök/közgazdász oktató specializáció).

- A MüMe mesterszakos képzésben a képzési kínálat bővítése (logisztikai és ellátási lánc menedzsment specializáció)

- Szakképzés-szakoktatás; szakképzés - pedagógia alapszakos specializációk indítása a müszaki és a gazdasági szakokon 2021-2022-1 félévtől.

- A 7 féléves alapszakos képzésekre épülő 3 féléves alapszakos szakmérnöki képzések (például EHS, karbantartó, minőségmenedzsment, folyamat szakmérnök). Ezen szakmérnöki képzések moduljai egymástól függetlenül külön-külön is elvégezhetők tanfolyami képzésként (3 félév 3 különböző modulból állna).

- Céges duális képzési megállapodások körének bővítése.

Az iskolarendszeren kívüli képzések esetében:

- Nem akkreditált, 20-30 órás, testre szabott, tudás átadó vagy tudás felfrissítő céges tanfolyamok a cégek igényeinek megfelelően az alábbi területeken:

○ Hiba diagnosztika (rendszerszemléletü hibaanalízis; hogyan lehet elindulni egy álló gépnél, hogy gyorsan megtaláljuk a probléma okát és elhárításának módját)

○ Vezérléstechnikai alapok (elektronikus és pneumatikus). Erre példa a BecktonDickinson Kft. részére megtartott „Vezérléstechnikai alapok technikusoknak”, vizsgával záruló, gyakorlat-orientált tanfolyam

○ Csapágytechnológiák, CNC technológiai alapok (előtolások, fordulatszám, hőkezelési és forgácsolási, vágási alapok)

○ Projektmenedzsment alapok, valamint vállalatgazdaságtani alapok (jövedelmezőségi, megtérülési, beruházásgazdaságossági számítások)

○ EHS (környezetvédelmi, munka és egészségbiztonsági alapok), ADR/RID (veszélyes anyagok kezelése, közúton és vasúton történő szállítása)

○ Elemző szakemberek képzése, amíg nem terjednek el a mesterséges intelligencia alapú megoldások.

○ Teljes eszközhatékonysági (Overall Equipment Effectivness) mutatók feljavítására képes szakemberek oktatása 
- Az alapszakos specializációk tárgyainak felhasználásával 30-60 órás tanfolyamok (például mérnök/közgazdász oktatói) a tematika „testre szabottan igazodik megrendelő egyedi igényeihez.

- A Lézer Zentrum Hannover (LHZ) képzésnek magyarosítása alapján akkreditált lézerbiztonsági szakértői (LSO) tanfolyamok (16 óra elmélet és külön 8 órás gyakorlat, mely modulok külön-külön is elvégezhetök). A munkavédelmi, veszélyes anyagok kezelése, sugárzásvédelmi, munkajogi fókuszú képzés mindazon szakembereknek ajánlható, akik a lézerek müködésének megismerése mellett átfogó biztonsági ismereteket is kívánnak szerezni.

- Az alapszakos műszaki képzésben a Folyamatok fejlesztése Six Sigma tantárgyhoz kapcsolódóan a „Zöld Öves” (Green Belt) igazolás kiadás feltételeinek megteremtése.

- 2026. január 1-től csak Akkreditált Vizsgaközpontokban lehet nappali és felnőttképzésben vizsga révén képesítő bizonyítványt (szakmát) szerezni. A technikumok/szakiskolák és az iskolarendszeren kívüli tanfolyamok szervezői csak tanúsítványokat adhatnak ki bárminek az elvégzéséről. Az Akkreditált Vizsgaközpontoknak lehetnek telephelye is, például az Edutus Egyetemen Tatabányán (akkreditált vizsgáztatás, mint szolgáltatás).

- Technikumi érettségi felkészítők és nyelvvizsga felkészítők kiszervezése az Edutus Egyetemhez.

Kutatás-fejlesztés-innováció (Regionális vállalkozó egyetemként innovációs csomópontként (hub) müködés Komárom Esztergom megyén belül).

- Stratégiai jellegü, hálózatos együttmüködések (közös projektek, osztott kutatási infrastruktúra használat, nemzetközi együttműködések. (Erre példa a Edutus EgyetemBridgestone Tatabánya Termelő Kft. vagy az Edutus Egyetem-B\&O Engineering Kft. együttmüködés)

- Alacsony költséggel minőségbiztosítási labor háttérszolgáltatások, egyedi jellegü ipari megbízások teljesítése

- Az oktatási-kutatási infrastruktúra fejlesztésék folytatása, a réspiaci ipari megbízások megszerzése esélyeinek növelése érdekében

- Vállalatoknál kihelyezett Edutus tárgyaló létesítése, és itt Edutus Egyetemi plakátok, roll-up-ok, szóróanyagok elhelyezése (Fanuc Hungary Kft - Törökbálint; B\&O Engineering Kft - Komárom) 
- Vállalati partnerekkel együtt cégek megkeresése, fejlesztési igényeik feltérképezése. Ezekre komplex csomag kidolgozása, validálása és értékesítése (technológiai, szolgáltatási és tréning megoldások). Erre példa lehet: „Jövő technológiái” címmel konferenciák meghirdetése - még kell nézni, hogy a megyéből ezekre kik jönnek el és milyen elvárásaik vannak. Ezeket szintén be lehet csatornázni a tananyagfejlesztésekbe, szolgáltatások nyújtásába.

- Az Innovációs és Technológiai Minisztérium Foglalkoztatáspolitikai Államtitkárságával kialakult szakmai egyeztetések alapján egy Komárom-Esztergom Megyei (KEM) lehetséges munkaerőpiaci pilot projekt kialakításában való közremüködés. A MIPA - Modern Ipari Alapképzés, mint ernyőmárka - mely egyben minőségbiztosítás az ország egyes régiói és a különböző szakmák esetében egységesen jelenik meg, az adott helyi és szakmai sajátosságokkal kiegészítve. A MIPA 3+2 elemből álló, modul jellegü tanfolyamokat adó program (a) Személyiségfejlesztés (HR) modul; b) Digitális kompetenciák modul; c) Szakmai kompetenciák modul (ágazatspecifikusan); d) Lean modul (folyamat érettség); e) Projekt menedzsment modul - sok cégnél a munkavégzés egyre inkább eltolódik projekt alapú tevékenységek irányába. A cél, hogy országos szinten minden megyében induljon el egy olyan „,pilotprogram”, amely egyrészt lefedi a helyi munkaerő piac igényeit, másfelől a programban érintett munkavállalók tovább tudnak lépni az elsődleges munkaerő piac irányába, vagy abban tovább maradnak, kevésbé „fluktuálódnak”. A MIPA digitális moduljait mindenhol az Edutus Egyetem Müszaki Intézete fogja csinálni, amely széleskörü vállalati kapcsolatokkal rendelkezik.

Nemzetközi együttmüködésekben rejlő lehetőségek kiaknázása

- Az Edutus Egyetem hagyományos Nemzetközi Hét rendezvényére rászervezve, vagy attól függetlenül egy saját, a későbbiekben jól „márkásítható” workshop sorozat indítása Edutus International Scientific Workshop (EDIW - évszám) néven. Az évente egy alkalommal megrendezendő multidiszciplináris jellegü, nemzetközi rendezvény előadói a Nemzetközi Hétre egyébként is meghívandó hazai és külföldi oktatók köréből kerülnének ki. Az EDIW előadások publikáció lehetőséget biztosít az egyetem tudományos folyóiratának, az Acta Periodica angol nyelvü különszámának a megjelentetésére is.

- Nemzetközi felsőoktatási együttmüködések kiszélesítése (Erasmus oktatói, hallgatói mobilitás lehetőségeinek az eddigeknél jobb kihasználása), kettős diplomás képzések 
beindítása (Edutus Egyetem - University of Aalen (Germany, illetve Edutus Egyetem Faculty of BuinessEconomics and Entrepreneurship (FBEE/VSPEP -Serbia) először gazdasági vonalon, majd később müszaki vonalon is (más partnerrel)

- „Testvér egyetem” típusú kapcsolat kialakítása a dániai Odense Egyetemmel (ttps://www.sdu.dk/en/om_sdu/). A Dél-dániai Egyetem (eredeti nevén Syddansk Universitet) az Odense-i Egyetem, a Dél-dániai Üzleti és Műszaki Egyetem és a Déljyllandi Egyetemi Központ egybeolvadásával jött létre 1998-ban. A Dél-dániai Egyetem 5 karral - ezeken belül 32 tanszékkel és 11 kutatási központtal - rendelkezik és az egyetemhez tartozik a Dél-dániai Egyetemi Könyvtár is. Az intézmény campusain (Odense, Slagelse, Kolding, Esbjerd és Sønderborg) 3800 fö alkalmazott (ebből 1200 fő kutató) dolgozik, a hallgatók száma pedig hozzávetőlegesen 27 ezer, amelynek 20 százaléka külföldi diák. A helyi vállalatokkal való széleskörü, szoros és példaértékü együttmüködésüknek köszönhetően a dán ipar három meghatározó vállalata is segítette adományaikkal az egyetem munkáját: a Maersk egy robotok fejlesztésével is foglalkozó központ, a Danfoss pedig egy elektronikai eszközök intelligensebbé tételével foglalkozó intézmény müködését támogatja, míg a Lego az egyetem gyermekek viselkedését és fejlődését vizsgáló kutatást segít. Az Odense Egyetem elindított oktatási portfoliójának bővítése érdekében egy automatizálási/robotizálási szakirányt. Eddig 1000 cég jött létre a szakirányhoz kapcsolódó kutatási projektek révén létrejövő innovatív megoldásokra, amelyek használható tudásként jelennek meg a piacon.

\section{Módszertani megjegyzések}

Az államilag elismert, magánegyetemként müködő Edutus Egyetem Komárom-Esztergom megye (KEM) egyetlen felsőoktatási intézményeként regionális innovatív tudás-és vállalkozói csomópontként (hub) müködve járul hozzá a megye gazdasági és társadalmi szereplői közötti hálózatos együttműködések erősítéséhez, a helyi munkaerőpiac és vállalatok visszajelzései alapján oktatási, kutatás-fejlesztési és tudáshasznosítási tevékenysége színvonalának javításával, képzési, szolgáltatási portfóliójának bővítésével. Jövőbeli térségi szerepét és mozgásterét meghatározzák a megye adottságai, a 2021-2027 időszakra szóló EU célokhoz való illeszkedés.

Az előző 2014-2020 időszak egyik meghatározó fejleménye volt, hogy a jogelőd Edutus Főiskola Tatabánya MJV-val, Esztergom városával és a Suzuki Zrt-vel közös pályázata alapján az 1206/2014 (IV.1) Korm. határozat szerint Tatabánya és Esztergom térsége kiemelt jármüipari központtá vált, lehetővé téve KEM térségének hazai és nemzetközi 
versenyképességének erősítését. Az Edutus Főiskolának a Tatabánya MJV és KomáromEsztergom megye integrált terület- és településfejlesztési stratégiáinak (TOP) megvalósításába és a GINOP projektekbe történő egyenrangú bekapcsolódását az Emberi Erőforrás Fejlesztési Operatív Program (EFOP) dedikált forrásai tették lehetővé. (EF ITF 2016; 1-2 oldal).

Az Intelligens Szakosodási Stratégia (Smart Specialization Strategy, S3) egy speciális, területi alapú és specializációs irányok kialakítására fókuszáló szakpolitikai eszköz, amelyet az Európai Unióban a 2014-2020-as időszak óta alkalmaznak, hogy az Operatív Programok forrásfelhasználása az egyes tagországok nemzeti adottságait tükröző S3 dokumentumaiban megfogalmazott horizontális és ágazati célrendszerekhez illesztve hatékonyan történjen meg javítva a társadalmi kohéziót, és gazdasági versenyképességet. Az előző programozási időszaknál Magyarország S3 dokumentumában felvázolt jövőkép szerint KEM az ipari termelési zónák közé tartozik, melyek jellemzője a gyártás, feldolgozóipar és az intenzív vállalati $\mathrm{K}+\mathrm{F}$ jelenlét dominál. A meghatározott szakosodási területeken az érintett szereplők be tudnak kapcsolódni az innovációs láncba, nagy hozzáadott értékű termékek fejlesztése révén sikeres beszállítókká válnak, elsősorban a KKV szektor megerősödésével. A fenntartható növekedési pályára állással a régióknak lehetőségük nyílik arra, hogy saját tudásközpontokat hozhassanak létre a szakosodási irányaik mentén, ezáltal tudásrégióvá váljanak. (Nemzeti Intelligens Szakosodási Stratégia 2014, 46-48.oldal; 60-61 oldal)

A 2021-2027-es időszakra vonatkozó S3 kialakítása az Innovációs és Technológiai Minisztérium szakmai felügyelete mellett, az NKFI Hivatal koordinálásával 2019 végén kezdődött meg. A 2021-2027 fejlesztési ciklusban az intelligens szakosodási stratégiák célja, hogy hozzájáruljanak az EU „Intelligensebb Európa az innováció és a gazdasági átalakulás, modernizáció támogatásával” szakpolitikai céljának megvalósításához. Az Európai Bizottság a korábbi nagyszámú tematikus prioritás helyett öt szakpolitikai célt határozott meg a 2021-2027es programozási időszakra, amelyek az EU aktuális kihívásaira adhatnak adekvát választ: 1) Intelligensebb Európa - innovatív és intelligens gazdasági átalakulás; 2) Zöldebb, karbonszegény Európa; 3) Jobban összekapcsolt Európa - mobilitás és regionális IKTösszekapcsoltság; 4) Szociálisabb Európa - a szociális jogok európai pillérének végrehajtása; 5) A polgárokhoz közelebb álló Európa - a városi, vidéki és part menti térségek fenntartható és integrált fejlesztése helyi kezdeményezések révén. (Magyarország Intelligens Szakosodási Stratégiája 2021-2027; 2. oldal)

A jelenleg kidolgozás alatt álló, következő időszakra szóló S3 dokumentum figyelembe veszi a Nemzeti Digitalizációs Stratégia 2021-2030 (NDS 2020), valamint a magyar mikro-, kis- és 
középvállalkozások megerősítésének stratégiája 2019-2030 (KKV Stratégia 2019) anyagokban foglaltakat is. Eszerint a nemzetgazdasági kulcsterületek magukban foglalják többek között a gazdaság digitalizációját, a korszerü, élvonalbeli technológiák elterjesztését, az erőforrás hatékony termelési módszerek megvalósítását, valamint horizontális prioritásként az ehhez szükséges tudás átadáshoz szükséges egyetemi és közszféra innovációkat, beleértve a gazdaság igényein alapuló iskolarendszerü és azon kívüli képzéseket, oktatásmódszertani elemeket.

Az Edutus Egyetemnek el kell készítenie az újabb négyéves időszakra szóló Intézmény Fejlesztési Terv 2021-2024 dokumentumot, hogy jogosult legyen a következő pénzügyi időszak közösségi, hazai és EU pályázati forrásainak igénybevételére. Az IFT 2021-2024 anyagnak egyaránt figyelembe kell vennie a hazai kormányzati és EU szakpolitikai dokumentumok elvárásait, valamint a KEM jelenlegi gazdasági-társadalmi környezetét. Ennek kapcsán jelen cikk elemzi a KEM műszaki képzéseit és az Edutus Egyetem vállalati kapcsolatait koordináló Müszaki Intézet (MIT) jövőbeli térségi szerepének lehetőségeit, megfogalmazva néhány, mind a megye, mind az Edutus Egyetem számára kitörési pontot jelentő javaslatot is. Ezek inputként szolgálhatnak az egyetem vezetése számára segítve a felkészülést az elkövetkező évek kihívásaira.

Mivel a 2021. évre áthúzódó COVID-19 járvány gazdasági kihatásai egyelőre nem prognosztizálhatók, ezért már a tervezési időszakban nagy rugalmasságra lesz szükség a célok és az erőforrás allokációk döntéselőkészítésében.

Az elemzésből levont főbb következtetések a szerző saját szakmai véleményét tükrözik.

\section{KÖSZÖNETNYILVÁNÍTÁS}

Jelen munka a "Lézertechnológiai és energetikai alapkutatás megvalósitása az Edutus Főiskolán, tudástranszfer, továbbá a vállalati kapcsolatok és a társadalmi szerepvállalás erösitését célzó tevékenységekkel kiegészítve" project keretében valósult meg. Projekt azonosító száma: EFOP-3.6.1-16-2016-000.

Az elemzés eredményei, megállapításai és javaslatai a “Kis és középvállalati versenyképesség vizsgálata a regionális adottságok kiaknázása szemszögéböl. Komárom-Esztergom megyei (KEM) esettanulmány” címü $\mathrm{PhD}$ kutatási témán alapulnak. 


\section{FELHASZNÁLT IRODALOM}

1. A magyar mikro-, kis- és középvállalkozások megerősitésének stratégiája 2019-2030, Innovációs és Technológiai Minisztérium Budapest, 2019

2. Cesar A. Hidalgo; Ricardo Hausmann: The building blocks of economic complexity Proceedings of National Academy of Sciences of the United States of America (PNAS) Vol 106, No 26, pp 10570-10575 (2009) doi: 10.1073_pnas.0900943106, ISSN: 1091-6490

3. Edutus Föiskola Intézményfejlesztési Terve 2016-2020, Tatabánya, 2016

4. Fekete Dávid: Európai jármüipari térségek gazdasági kormányzási modelljei; Tér és Társadalom 125-142 oldal, 31. évf., 3. szám, 2017 doi:10.17649/TET.31.3.2746; ISSN: 2062-9923 (online); ISSN 0237-7683 (print)

5. Gazdaságfejlesztő Szervezet (GFSZ) Tatabánya Belső Információs Rendszerének adatszolgáltatása 2020.

6. HIPA Automotive Industry in Hungary 2019.

7. Laki Balázs: „Az innováció-vezérelt tudásalapú társadalom lehetőségei az Edutus Egyetem és a szerb FBEE (VSPEP) együttmüködésében” előadás, Magyar Tudomány Ünnepe 2020 „ Jövőformáló Tudomány” tudományos konferencia, EFOP 3.6.1. projekt aktuális eredményei - Müszaki tudományok és vállalati együttmüködés szekció Edutus Egyetem 2020. november 27.

8. Magyarország Intelligens Szakosodási Stratégiája 2021-2027. Háttéranyag az S3 prioritások szakmai validációjába bevont szervezetek részére Innovációs és Technológiai Minisztérium, Budapest, 2019.

9. Magyarország 2019 Központi Statisztikai Hivatal (2020) Budapest, ISSN: 1416-2768, Nyilvántartási szám: Y/11165

10. Nemzeti Digitalizációs Stratégia (NDS) 2021-2030. Partnerségi konzultációra bocsátott, nem végleges változat. Innovációs és Technológiai Minisztérium, Budapest 2020, https://docplayer.hu/192396259-Nemzeti-digitalizacios-strategia.html keresőprogram: Google, kulcsszavak: NSD lekérdezés: 2020.12.23.

11. Nemzeti Intelligens Szakosodási Stratégia 2014-2020, Nemzeti Innovációs Hivatal (NIH), Budapest, 2014

12. Nick Routley: Countries Ranked by Their Economic Complexity, Visual Capitalist 2019 https://www.visualcapitalist.com/countries-ranked-by-their-economic-complexity/ keresőprogram: Google, kulcsszavak: economic complexity ranking lekérdezés: 2020.12.19.

13. OECD (2019) Economic Surveys: Hungary 2019, OECD Publishing, Paris https://doi.org/10.1787/eco_surveys-2019-hun-en ISBN 978-92-64-31124-4 (print); ISBN 978-92- 64-31125-1 (online)

14. Rechnitzer János; Hausmann Róbert; Tóth Tamás: A magyar autóipar helyzete nemzetközi tükörben Hitelintézeti Szemle, 16. évf. 1. szám, 2017. március, 119-142. o. ISSN 15886883 (Nyomtatott); ISSN 2416-3201 (Online) 

http://paktum.gfsz.hu/feltoltesek/Dokumentumok/STRAT\%C3\%89GIA_Tatab\%C3\%A1n ya.pdf keresőprogram: Google, kulcsszavak: foglalkoztatási paktum, Komárom-Esztergom megye foglalkoztatási stratégia, Tatabánya, lekérdezés: 2020.10.05.

16. Tóth Cs. L. (2007): A karcsúsitott gyártás - a lean production. Magyar Minőség, 8-9., 213.

17. Túry Gábor: Technológiai és munkaszervezési újitások hatása az autóipar térbeli szerveződésére - iparági példa a Volkswagen mintáján; Tér és Társadalom 44-64 oldal, 31. évf., 2. szám, 2017 doi:10.17649/TET.31.2.2841, ISSN: 2062-9923 (online); ISSN 02377683 (print) 